繊維強化複合材シェルの曲面形状と積層構成の統合最適化*

\author{
本田 真也 ${ }^{* 1}$, 加藤 大翔 ${ }^{* 2}$, 成田 吉弘 ${ }^{* 3}$, 成田 大祐 ${ }^{* 4}$
}

\title{
Multidisciplinary Design Optimization of Surface Shapes and Lay-Up Configurations for Composite Laminated Shells
}

\author{
Shinya HONDA ${ }^{* 1}$, Takeru KATO, Yoshihiro NARITA and Daisuke NARITA \\ ${ }^{* 1}$ Hokkaido Univ., Dept. of Human Mechanical Systems \& Design \\ N13W8, Kita-ku, Sapporo, 060-8628, Hokkaido, Japan
}

\begin{abstract}
Shapes and lay-up configurations of composite laminated shallow shells are optimized simultaneously to maximize the fundamental frequency by a simple genetic algorithm method. The shell shape is defined by a cubic polynomial and this makes it possible to express various shapes of shells with inconstant curvature radii by varying the value of coefficient for each term. The coefficients and the lay-up configuration of the laminated shell are directly employed as design variables, and constraints are imposed on the coefficients and curvature radii to keep shells shallow. The frequencies are calculated by using the Ritz method due to its flexibleness for shell shapes. Results of the present analysis technique agreed well with experimental and finite element analysis results in terms of frequencies and mode shapes. Obtained optimum solutions resulted in higher fundamental frequencies than the shells with general shapes and lay-up configurations.
\end{abstract}

Key Words : Shallow Shell, Composite Material, Ritz Method, Genetic Algorithm, Optimization, Experimental Modal Analysis

\section{1. 緒言}

工業分野における繊維強化複合材の利用は, 近年ますます拡大してきている. 繊維強化複合材は, その比強度・ 比剛性の大きさから輸送機器等の軽量化材として期待され, 活発に研究・開発が行われきた. その結果, 近年で は自動車などの外装パネルにまで応用されている。一般に外装パネルはシェル構造であり，その多くは曲率の小 さな偏平シェルである. 輸送機器などの外装パネルに要求される設計要素は, 引張や圧縮強度よりも, 乗り心地 や操綐安定性能に関連する曲げ岡性や振動特性である. シェル構造の振動特性はその形状に大きく依存するため, シェル構造の形状に対する振動特性変化の解明は重要である．また，繊維強化複合材は繊維を一方向に引き揃え たラミナと呼ばれる薄い層の配向角度を変化させながら積層し，積層複合材として利用されている．複合材の振 動特性はその積層構成に依存するため, 積層構成を最適に設計することが重要な要素と言える. 本研究では, 複 合材シェルの基本振動数を最大化する目的で，シェル形状および，䋊維配向角度を同時に設計する手法を提案す る.

シェル構造の振動特性に関する研究報告は過去に数多く存在し，偏平シェルに関する最近の研究進展を取りま

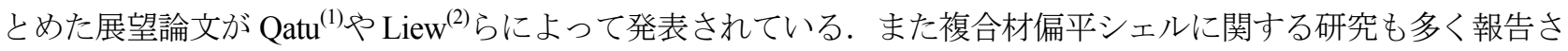
れている. Lam ら ${ }^{(3)}$ は固定端を有する積層複合材シェルの動解析を行っており， Berçin ${ }^{(4)}$ は $0^{\circ}$ 層と $90^{\circ}$ 層を交互に 積層したクロスプライ積層を有するシェルの振動数を算出している. Bardell ら ${ }^{(5)}$ は円筒型の複合材シェルの自由

\footnotetext{
* 原稿受付 2010 年 11 月 12 日

${ }^{*}$ 正員, 北海道大学 工学研究院（ $\overline{0} 060-8628$ 北海道札幌市北区北 13 条西 8 丁目）

${ }^{* 2}$ 北海道大学 大学院工学研究科（干060-8628 北海道札幌市北区北 13 条西 8 丁目）

*3 正員, フェロー, 北海道大学 大学院工学研究院 (

${ }^{* 4}$ 正員, 北海道自動車短期大学（广062-0922 北海道札幌市豊平区中の島 2 条 6 丁目 2 番 1 号)

E-mail: honda@eng.hokudai.ac.jp
} 
および強制振動の解析を行い, Selmane ら ${ }^{(6)}$ も異方性円筒シェルの解析を行っている. Soldatos ら ${ }^{(7)} は フ$ シ゚ラマイ ナスの繊維配向角度を交互に積層するアングルプライ積層を有する円筒シェルの境界条件のおよび面外せん断力 が振動数に与える影響を考察しており, Kabir ら ${ }^{(8)}$ は任意の積層構成を有する円筒シェルの応答解析を行っている. また国内でも活発な研究が行われ，シェルの座屈や振動に関してまとめたハンドブック(9)も発表されている．複 合材偏平シェルの最適化に関しては Raouf ${ }^{(10)}$ が綫維配向角度による複合材シェルの動的応答への影響を調査して おり，また著者ら ${ }^{(11),(12)}$ は遺伝的アルゴリズムや層別最適化(LO)法を用いて基本振動数の最大化に取り組んでいる. しかしながら，先にあげた研究では，全て均一な曲率を仮定しており，曲率半径をシェルの領域内では一定とし ている，実用上のシェル構造は非均一な曲率を有しており，複雑な形状をしている，そのため著者ら ${ }^{(13)}$ は，曲面 形状を多項式によって定義し，任意の曲面構造を持つ偏平シェルの振動解析手法を提案した。本報では文献 ${ }^{(13)}$ で 提案した解析手法を応用し，基本振動数の最大化問題へと応用寸る.

積層複合材シェルの基本振動数最大化を目的として，シェル形状及び積層構成を設計変数とした統合最適化手 法を提案する. 任意の曲率を持つシェル形状は三次の多項式により定義し, 各項の係数を変化させることで, 曲 面形状を制御する．また，振動数方程式の導出には Ritz 法を用いる．Ritz 法は曲面形状の変化をパラメータ変化 により表現可能なため, 本報のような曲面形状最適化問題に適している. 最適化問題の設計変数はシェル形状を 定義する多項式の係数，および積層複合材を構成する各層の繊維配向角度とする. 纎維配向角度は離散的な值か ら構成されることから，本問題は組合せ最適化問題となる，そのため，最適化手法には組合せ最適化問題に効果 的な遺伝的アルゴリズム(Genetic Algorithm: GA)を用いた.

最適化計算の結果, 本手法で得られた積層構成およびシェル形状を有する複合材は他の一般的な複合材シェル よりも高い振動数を有していた。また，得られた結果よりハンドレイアップ成形法により試験片を作製し，実験 モード解析を行った結果，最適な積層構成および形状を有する複合材シェル試験片は他の試験片より高い振動数 を有していた，なお，本報では，外部共振を避けるための対策として，基本振動数を最大化を行ったが，高次の 振動数を目的関数とすることも可能である. また，目的関数を所望の振動数との二乗差とし，その差を最小化す ることで所望の振動数設計を行うことが可能となるため, シェル構造物の設計手法として幅広く応用可能である.

\section{2. 解析手法および最適化問題}

\section{$2 \cdot 1$ 不均質な曲率を持つ複合材シェル}

本報では，Ritz 法により図 1 に示すような不均質な曲率を有する複合材シェルの固有振動数を算出する. 任意 の曲率を有するシェル形状は, 汎用有限要素法(FEM)に組込まれているシェル要素を用いることで固有振動数解 析が可能である. しかしながら，FEM を用いると，シェル形状が変化する際に，再びモデルを作製し直す必要が あり，容易ではない，そのため，繰返し計算が必要となる最適化問題には適さない，本報ではパラメータ操作に より容易にシェル形状を変化させることが可能な Ritz 法を採用する.

図 1 に示寸ように, 水平面に射影した際に $a \times b$ の寸法となる長方形シェルを考え, $O-x y$ 平面からのシェル中 央面の高さを $\phi$ として, $x, y$ の三次多項式

$$
\phi(x, y)=c_{20} x^{2}+c_{11} x y+c_{02} y^{2}+c_{30} x^{3}+c_{21} x^{2} y+c_{12} x y^{2}+c_{03} y^{3}
$$

によりシェル形状を表現する. ここで,$c_{p q}(p, q=0,1,2,3)$ は曲面を決定する形状係数であり，任意の形状を表現 する際には, シェル形状の主要点を選んで内挿を行うことで求める.

曲率が大きく変化しない仮定, 寸なわち, $(\partial \phi / \partial x)^{2}=(\partial \phi / \partial y)^{2}<<0$ の仮定の下で, 曲率は式(1)の二階微分により 求めることができ, 以下となる.

$$
\frac{1}{R_{x}}=2\left(c_{20}+3 c_{30} x+c_{21} y\right), \frac{1}{R_{y}}=2\left(c_{02}+c_{12} x+3 c_{03} y\right), \frac{1}{R_{x y}}=c_{11}+2 c_{21} x+2 c_{12} y
$$




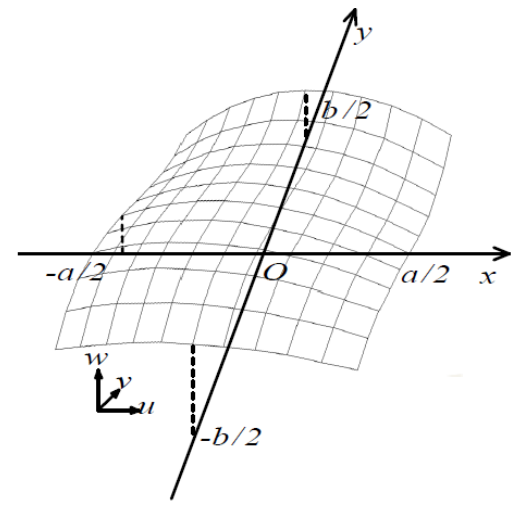

Fig. 1 The coordinate systems $O-x y z$ for the present shell.

\section{$2 \cdot 2$ 同時最適化問題}

最適化問題においては，対称 8 積層複合材偏平シェルの基本振動数 $\Omega_{1}$ の最大化を目的として，式(1)における 各項の係数 $c_{p q}(p, q=0,1,2,3)$ 及び各層の繊維配向角度 $\theta_{i}(i=1,2,3,4)$ を設計変数とした. ここで, 形状係数はそ れぞれ 0.01 刻み, 積層構成の繊維配向角度は 5 刻みで変化させた. また, 繊維配向角度は, 図 1 に示す $x$ 軸より 反時計周りを正として定義し，シェル表面に射影されるものとする. 形状係数 $c_{p q}$, 曲率 $1 / R_{x}, 1 / R_{y}, 1 / R_{x y}$ に関し ては偏平シェルとみなせる範囲に収まるように制約を与え，積層構成には特に制約を与えない，以上により，本 報における最適化問題は以下のように定式化できる.

Maximizing: $\Omega_{1}$

Design variable: $c_{p q}(p, q=0,1,2,3), \theta_{i}(i=1,2,3,4)$

Subject to : $-0.20 \leq c_{p q} \leq 0.20,-0.5 \leq \frac{a}{R_{x}}, \frac{a}{R_{y}}, \frac{a}{R_{x y}} \leq 0.5$, $-90^{\circ}<\theta_{i} \leq 90^{\circ}$

最適化手法には，基本的な遺伝的アルゴリズム(GA)を用いる ${ }^{(14)}$. それぞれの個体(曲率および繊維配向角度)の 遺伝子型は二進数により表現し，ルーレット法により親個体の選択を行った。ここで，形状係数 $c_{p q}$ はそれぞれ 10 桁, 繊維配向角度 $\theta_{i}$ はそれぞれ 6 桁の遺伝子でコーディングしており, 各個体は 94 桁の染色体長を有する. GA オペレータとしては，二点交叉と突然変異を採用した．ただし，図 2 に示すように，二つの交叉点は前半部 の形状係数 $c_{p q}$, 後半部の積層構成 $\theta_{i}$ の遺伝子型に対してそれぞれ一点ずつ来るように定義する. すなわち, それ ぞれの設計変数に対しては一点交叉となる.

また, 各世代において最も適応度の高い個体の内, 数体をそのまま次世代に引き継ぐエリート戦略を適用した. これにより, 目的関数 $\Omega_{1}$ が単調増加となり, 解の発散を防ぐことができる. 最適化問題中で定義した偏平シェル の範囲を超えて制約条件を犯す個体に対しては，その目的関数にペナルティを与え，適応度を小さくする操作を 行った．ただし，ここでは遺伝子の多様性を保つために，制約を犯す個体を除外するのではなく，親個体として 選択される可能性を小さくするに留めている.

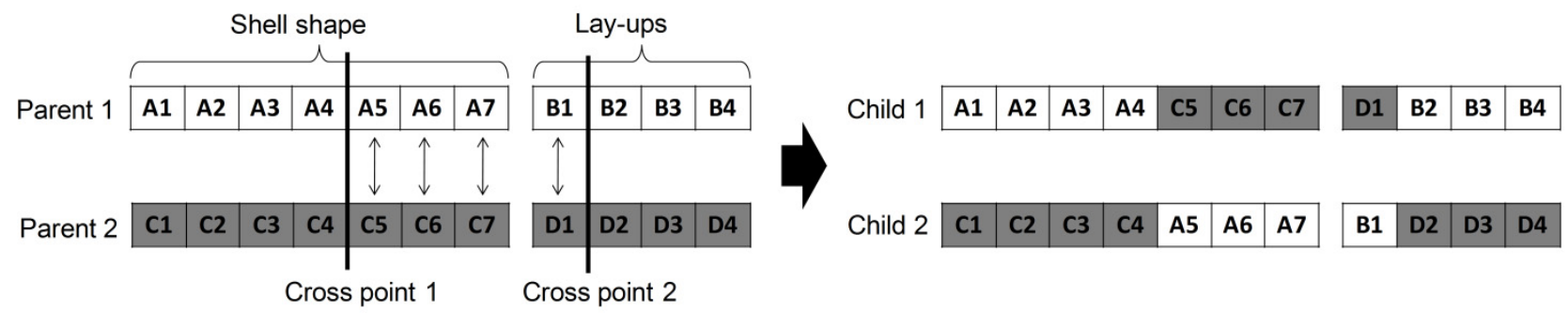

Fig. 2 An example of the present two point crossover. 


\section{$2 \cdot 3$ Ritz 法によるシェルの振動解析 ${ }^{(13)}$}

本報で扱うシェルは Donnell 型のシェル理論に基づくと仮定する. Donnell 型のシェル理論では, シェル中央面 の変位 $u, v, w$ とひずみ $\varepsilon_{x}, \varepsilon_{y}, \gamma_{x y}$ の関係は,

$$
\varepsilon_{x}=\frac{\partial u}{\partial x}+\frac{w}{R_{x}}, \quad \varepsilon_{y}=\frac{\partial v}{\partial y}+\frac{w}{R_{y}}, \quad \gamma_{x y}=\frac{\partial u}{\partial y}+\frac{\partial v}{\partial x}+\frac{2 w}{R_{x y}}
$$

となる. 従来の一定曲率シェルの解析との相違点は, 式(3)の曲率半径 $R_{x}, R_{y}, R_{x y}$ が定数ではなく, 式(2)により与 えられる位置の関数となる点である.

Ritz 法を用いるため，シェル全体のエネルギを評価する．シェル全体に蓄えられるひずみエネルギは，

$$
V=V_{s}+V_{b s}+V_{b}
$$

となる，ここで， $V_{s}$ は面内変形によるひずみエネルギ， $V_{b s}$ は面内と面外のカップリングによるひずみエネルギ， V $V_{b}$ は面外変形によるひずみエネルギであり，それぞれ，以下となる.

$$
\begin{aligned}
& V_{s}=\frac{1}{2} \iint\{\varepsilon\}^{T}[A]\{\varepsilon\} d x d y \\
& V_{b s}=\frac{1}{2} \iint\left(\{\kappa\}^{T}[B]\{\varepsilon\}+\{\varepsilon\}^{T}[B]\{\kappa\}\right) d x d y \\
& V_{b}=\frac{1}{2} \iint\{\kappa\}^{T}[D]\{\kappa\} d x d y
\end{aligned}
$$

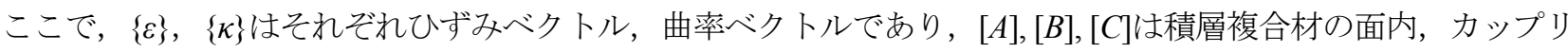
ング，面外に関する剛性マトリクスである. シェル中央面から第 $k$ 層外側までの距離を $z_{k}$ とすると，

$$
A_{m n}=\sum_{k=1}^{N}\left(\bar{Q}_{m n}\right)_{k}\left(z_{k}-z_{k-1}\right), B_{m n}=\frac{1}{2} \sum_{k=1}^{N}\left(\bar{Q}_{m n}\right)_{k}\left(z_{k}^{2}-z_{k-1}^{2}\right), D_{m n}=\frac{1}{3} \sum_{k=1}^{N}\left(\bar{Q}_{m n}\right)_{k}\left(z_{k}^{3}-z_{k-1}^{3}\right)
$$

となる. ここで, $\bar{Q}_{m n}(m, n=1,2,6)$ は各層において, 繊維方向座標から $O-x y$ 座標に座標変換された縮約剛性係数 であり, 各層の繊維方向 $\theta_{i}(i=1,2, \ldots, N)$ および繊維と垂直方向のヤング率 $E_{1}, E_{2}$, ポアソン比 $v_{12}$, およびせん 断弾性係数 $G_{12}$ により定義される ${ }^{(14)}$.

また，シェル全体の運動エネルギは，

$$
T=\frac{\rho h}{2} \iint\left[\left(\frac{\partial u}{\partial t}\right)^{2}+\left(\frac{\partial v}{\partial t}\right)^{2}+\left(\frac{\partial w}{\partial t}\right)^{2}\right] d x d y
$$

となる.ここで, $\rho$ は単位体積あたりの質量, $h$ は板厚である.

続いて, 変位 $u$ を以下のように定義する.

$$
u(\xi, \eta, t)=\sum_{i=0}^{I-1} \sum_{j=0}^{J-1} P_{i j} X_{i}(\xi) Y_{j}(\eta) \sin \omega t
$$

ここで, $P_{i j}$ は未定係数であり, $\xi=2 x / a$ および $\eta=2 y / b$ は無次元化座標である. $X_{i}(\xi), Y_{j}(\eta)$ は「境界条件イン デックス」 ${ }^{(15)}$ 用いて, 任意の境界上で幾何学的な条件を満足する関数であり, 以下のように定義する. 


$$
\left\{\begin{array}{l}
X_{i}(\xi)=\xi^{i}(1-\xi)^{b u 1}(1+\xi)^{b u 3} \\
Y_{j}(\eta)=\eta^{j}(1-\eta)^{b u 2}(1+\eta)^{b u 4}
\end{array}\right.
$$

ここで, $b u 1, b u 2, b u 3, b u 4$ は $u$ に関する長方形シェル各辺での境界条件インデックスである. $b u$ に続く各数字は 長方形の各辺を意味しており, 長方形左辺から反時計周りに 1 から 4 の順に対応している. ここで, 境界条件イ ンデックスの值が 1 の場合に固定辺を表し，0の場合は自由辺を表す. $v, w$ に関しても式(8), (9) と同様であるが, 面外変位 $w$ に関しては 0 のとき自由，1のとき単純支持，2のとき固定端を示す.

最大ひずみエネルギ $V$ および最大運動エネルギ $T$ の差により得られる汎関数 $F$ に対して, それぞれの未定係数 に関する極值を求めることで, 以下のような非均一の曲率を有する複合材シェルの振動数方程式が導出できる.

$$
\left(\left[\begin{array}{lll}
k_{11} & k_{12} & k_{13} \\
k_{12} & k_{22} & k_{21} \\
k_{13} & k_{21} & k_{33}
\end{array}\right]-\Omega^{2}\left[\begin{array}{ccc}
m_{11} & 0 & 0 \\
0 & m_{22} & 0 \\
0 & 0 & m_{33}
\end{array}\right]\right)\left\{\begin{array}{l}
P_{i j} \\
Q_{k l} \\
R_{m n}
\end{array}\right\}=0
$$

ここで， $k_{i j}, m_{i j}(i, j=1,2,3)$ はそれぞれ剛性行列，質量行列の要素であり， $Q_{k l}, R_{m n}$ は式(8)と同様に $v, w$ に関する 未定係数である. 式(10)より, 以下のような無次元化された固有振動数である振動数パラメータ $\Omega$ が得られる.

$$
\Omega=\omega a^{2} \sqrt{\frac{\rho}{D_{0}}}
$$

ここで, $D_{0}=E_{2} h^{3} / 12\left(1-v_{12} v_{21}\right)$ は基準剛性である.

\section{$2 \cdot 4$ 最適化結果}

本報では CFRP 材料を仮定し，弾性定数は， $E_{1}=138[\mathrm{GPa}], E_{2}=8.96[\mathrm{GPa}], G_{12}=7.10[\mathrm{GPa}], v_{12}=0.30$ とする．ま た, アスペクト比 $a / b=1.0$, 及び厚さ比 $h / a=0.01$ とする. 境界条件は曲面形状の左辺から反時計回りに四つ の文字で定義し, $\mathrm{F}$ は自由, $\mathrm{S}$ は単純支持, $\mathrm{C}$ は固定を表す. また, 変位関数の項数 $\left(I, J\right.$ など)は全て 10 とした ${ }^{(13)}$.

表 1 に 12 種類の境界条件に対して, 最適な曲面形状を表現する形状係数 $c_{p q}$ を示す. 表 2 には各境界条件にお いて, 本手法で求めた最大振動数パラメータおよび最適積層構成, 本手法で求めた最適曲面形状と同じ形状を持 ち，代表的な積層構成を有する積層偏平シェル中で最も高い值を示した振動数パラメータ，及びその差を示す． なお代表的な積層構成は[0/0/0/0]s, [90/90/90/90]s, [0/90/0/90]s, [30/-30/30/-30]s, [45/-45/45/-45]s, [0/-45/45/90]s の六 つを採用した，表 2 より，本手法で得られたシェルは，各境界条件において差はあるが，全境界条件で代表的な 積層構成を有するシェルと同様またはより高い振動数を与えていることがわかる．これにより，本手法の統合的 な最適化手法の有用性が確認できる，特に FFFF(全周自由), CFFF(片持ち), FSFS の境界条件では, 代表的な積 層構成よりも $10 \%$ 以上高い振動数を与えることがわかった.

また，図 3 (a)-(d)に代表的な四つの境界条件 CCCC, SSSS, FSFS, CFFF に関する上面から見た各層の最適な繊維 配向角(重合せた図), 及び最適な曲面形状を示す，それぞれ青が第一層，緑が第二層，赤が第三層，橙が第四層 の繊維を意味している．図3(a)の CCCC の拘束を持つシェルでは，一層目と二層目，三層目と四層目が垂直に交 差しており, 代表的な積層構成[45/-45/45/-45]s と同様である. 最適曲面形状は球形シェルと同様の形状を示した. 図 3(b)に示す SSSS の場合も同様の曲面形状が示されたため, 全周に一様な拘束がある場合, 球形状となる傾向 があると推測できる. 図 3(c)より, 振動数パラメータが大きく改善した FSFS では, 代表的な積層構成内で最も 高い振動数を与える[90/90/90/90]s と, 最適な積層構成では外側二層の角度が同様であるが, 内側の二層が大きく 異なる繊維配向角度を示している，曲げ振動では，外層ほど面外剛性 $D_{m n}$ に対する影響が強いが，今回得られた シェル形状および積層構成では, 内層である三層目, 四層目の配向角が振動数の向上に大きく寄与しており, 面 内剛性 $A_{m n}$ の振動数一の寄与も少なくないことがわかる. 得られた最適曲面形状は, 上記の CCCC とは大きく異 なり，馬鞍形シェルに一致した形状であった。 また，図3(d)に示す CFFF(片持ち)の場合も FSFS と比較して浅く 
はあるが，馬鞍形のシェル形状を与えている，積層構成は，代表的な繊維配向角度[30/-30/30/-30]s とは異なり， 第三層目に 0 層が含まれている.

Table 1 Optimum shape coefficients for the shallow shells with maximized fundamental frequencies

\begin{tabular}{cccccccc}
\hline B. C. & $c_{20}$ & $c_{02}$ & $c_{11}$ & $c_{30}$ & $c_{03}$ & $c_{21}$ & $c_{12}$ \\
\hline FFFF & 0.03 & 0.00 & -0.18 & 0.17 & 0.15 & 0.01 & 0.05 \\
SFFF & 0.02 & -0.17 & 0.03 & 0.00 & 0.00 & 0.02 & 0.15 \\
CFFF & -0.06 & 0.15 & -0.01 & -0.10 & 0.01 & 0.03 & -0.16 \\
SSFF & -0.09 & -0.15 & 0.20 & -0.07 & -0.03 & 0.10 & 0.12 \\
SCFF & -0.20 & 0.02 & 0.20 & 0.01 & 0.04 & 0.05 & -0.19 \\
CCFF & -0.11 & -0.15 & 0.19 & -0.02 & -0.01 & 0.14 & 0.16 \\
FSFS & 0.19 & -0.17 & -0.20 & 0.01 & -0.01 & 0.10 & 0.00 \\
SFCF & 0.00 & -0.20 & -0.20 & 0.06 & -0.02 & -0.19 & -0.04 \\
CFCF & -0.18 & 0.14 & 0.18 & 0.00 & -0.02 & 0.02 & -0.15 \\
SSSF & -0.05 & 0.16 & -0.18 & -0.11 & 0.03 & -0.15 & -0.01 \\
SSSS & -0.19 & -0.20 & 0.06 & 0.02 & -0.02 & 0.02 & 0.02 \\
CCCC & -0.17 & -0.19 & -0.04 & -0.03 & 0.00 & -0.03 & 0.11 \\
\hline
\end{tabular}

Table 2 The maximum fundamental frequency parameters for the shallow shells with optimum lay-ups and typical lay-ups.

\begin{tabular}{|c|c|c|c|c|c|}
\hline B.C. & Optimum frequency & Optimum lay-up & $\begin{array}{l}\text { Highest frequency } \\
\text { inTypical lay-ups }\end{array}$ & Typical lay-ups & Diference $[\%]$ \\
\hline FFFF & 60.9 & {$[15 /-60 / 75 / 45] \mathrm{s}$} & 53.0 & {$[0 /-45 / 45 / 90] \mathrm{s}$} & +14.9 \\
\hline SFFF & 31.7 & {$[30 /-45 /-15 /-15] \mathrm{s}$} & 29.5 & {$[30 /-30 / 30 /-30] \mathrm{s}$} & +7.67 \\
\hline CFFF & 33.5 & {$[-30 / 30 / 0 /-30] s$} & 29.5 & {$[30 /-30 / 30 /-30] \mathrm{s}$} & +13.6 \\
\hline SSFF & 103 & {$[-75 /-15 / 0 / 45] \mathrm{s}$} & 93.4 & [0/-45/45/90]s & +9.83 \\
\hline SCFF & 70.5 & {$[-60 / 45 / 30 / 90] \mathrm{s}$} & 66.4 & [0/-45/45/90]s & +6.14 \\
\hline CCFF & 104 & {$[-75 /-15 / 15 / 30] \mathrm{s}$} & 101 & [0/-45/45/90]s & +3.35 \\
\hline FSFS & 218 & {$[90 / 90 / 30 /-45] s$} & 182 & [90/90/90/90]s & +19.8 \\
\hline SFCF & 132 & [15/-30/30/-15]s & 123 & {$[0 / 0 / 0 / 0] \mathrm{s}$} & +7.72 \\
\hline CFCF & 258 & [0/15/-15/90]s & 251 & {$[0 / 0 / 0 / 0] \mathrm{s}$} & +2.56 \\
\hline SSSF & 88.4 & {$[-45 / 45 / 15 / 90] \mathrm{s}$} & 82.0 & {$[45 /-45 / 45 /-45] \mathrm{s}$} & +7.85 \\
\hline ssss & 330 & {$[75 /-45 / 30 / 30] s$} & 329 & [0/-45/45/90]s & +0.304 \\
\hline $\operatorname{cccc}$ & 366 & {$[15 /-75 / 60 /-30] \mathrm{s}$} & 347 & {$[45 /-45 / 45 /-45] \mathrm{s}$} & +5.48 \\
\hline
\end{tabular}




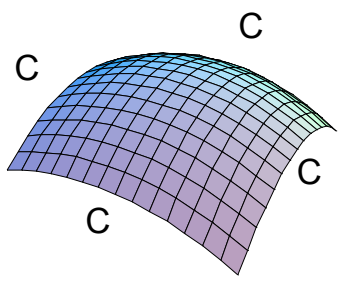

Optimum surface

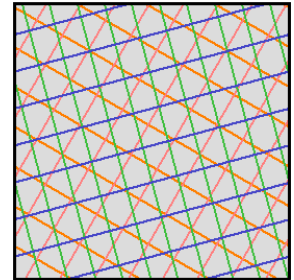

Overlapping

(a) $\operatorname{CCCC}$

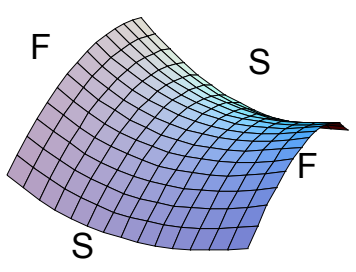

Optimum surface

(C)FSFS

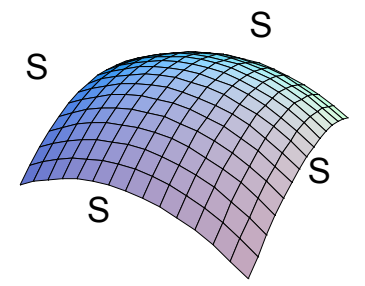

Optimum surface

\section{(b) SSSS}

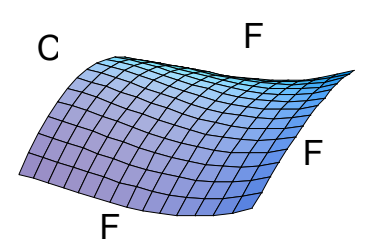

Optimum surface

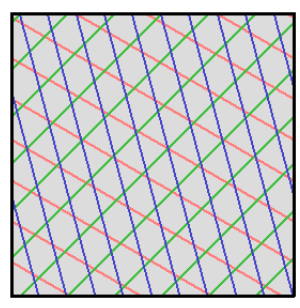

Overlapping

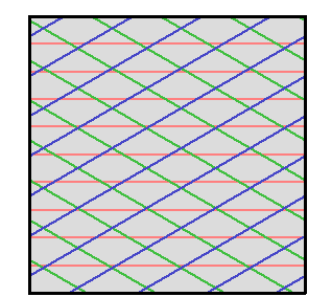

Overlapping

(d) CFFF

Fig. 3 The optimum shell shapes and lay-up configurations for (a) CCCC, (b)SSSS, (c)FSFS and (d) CFFF square shell with symmetric 8-layers.

\section{3. 実験手法および結果}

\section{$3 \cdot 1$ 試験片作製}

本手法の妥当性を検証するため，炭素繊維及びエポキシ樹脂を用いて試験片を作製し，最適な曲面および積層 構成を有するシェルと，他の曲面および積層構成を有するシェルの振動数を比較する. 本報で用いた試験片の作 製手順は以下の通りである.

1. 三次元 $\mathrm{CAD}$ にて，曲面形状を設計(図 4).

2. 三次元プロッターにて, ケミカルウッドより, 設計した曲面を削り出す(図 5).

3. ハンドレイアップ成形法にて，作製した型の間にCFRP シートを積層する.

4. 電気炉内で硬化 $\left(2\right.$ 時間 $\left.@ 120^{\circ} \mathrm{C}\right)$ し, 炉内で十分に冷却し, 完成(図 6).

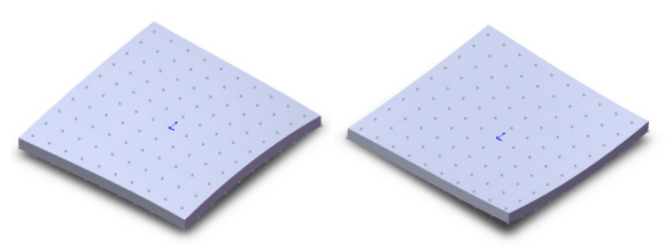

Fig. 4 Top and bottom surfaces

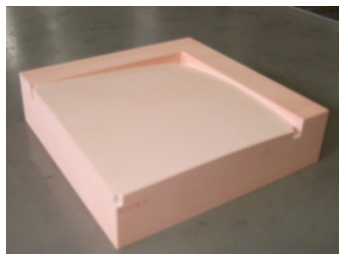

Fig. 5 Chemical wood mold

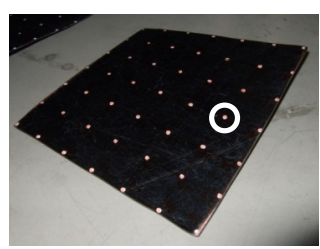

Fig. 6 Test specimen

\section{$3 \cdot 2$ 実験結果}

全周を自由端とした場合の最大基本振動数を与える曲面形状および積層構成を持つ試験片を作製し，振動数お よび振動モードを測定し，他の形状および積層構成を有するシェルと比較する．同様の材料を用いて，平板を作 成し, 引張試験により得られた材料定数は, $E_{1}=122.6 \mathrm{GPa}, E_{2}=7.85 \mathrm{GPa}, G_{12}=5.07 \mathrm{GPa}, v_{12}=0.338$ であった. 試 験片寸法は, $a=b=160 \mathrm{~mm}$, 板厚は概ね $2.5 \mathrm{~mm}$ である. 実験に用いる最適形状および積層構成を有するシェルを 算出する最適化問題において, 設計変数である形状係数 $c_{p q}$ に関しては前節と同様であるが, 積層構成は試験片製 作の簡易化のため対称 12 層とし，配向角度は $0^{\circ} ， 90^{\circ} の 2$ 通りからなる組合せに限定した. 
得られた形状係数は， $\left(c_{20}, c_{02}, c_{11}, c_{30}, c_{03}, c_{21}, c_{12}\right)=(0.01,0.01,0.19,0.14,0.03,0.00,0.10)$ であり，最適な積層構成 は[0/90/0/90/90/90]s であった．表 3 に，比較のために作製した五つの試験片の詳細を示す．試験片 1 は実験のた めに行った最適化計算によって求められた最適な曲面形状および最適な積層構成を有するシェルであり, 試験片 2，3 は最適な曲面形状を有するが，それぞれ一方向にのみ強化したシェルである. 試験片 $4 ， 5$ は最適な積層構 成を持つが，曲面形状は乱数により与えられたシェルである. 試験片 4,5 の曲面形状はそれぞれ， $\left(c_{20}, c_{02}, c_{11}, c_{30}\right.$, $\left.c_{03}, c_{21}, c_{12}\right)=(0.16,-0.14,0.02,0.14,-0.15,-0.09,-0.11),(-0.05,-0.14,-0.09,-0.08,-0.00,0.06,-0.17)$ とした. 図 7 に作製 した三通りの試験片形状を示す. ここでは最適化結果との比較を行うため, 最適な曲面形状と類似した形状を持 つシェルを採用した.

Table 3 Shell shapes and lay-up configurations of the five test specimens

\begin{tabular}{ccc}
\hline No. & Shell shape & Lay-up \\
\hline 1 & Opt. & Opt. [0/90/0/90/90/90]s \\
2 & Opt. & {$[0 / 0 / 0 / 0 / 0 / 0] \mathrm{s}$} \\
3 & Opt. & {$[90 / 90 / 90 / 90 / 90 / 90] \mathrm{s}$} \\
4 & Random & Opt. [0/90/0/90/90/90]s \\
5 & Random & Opt. [0/90/0/90/90/90]s \\
\hline
\end{tabular}

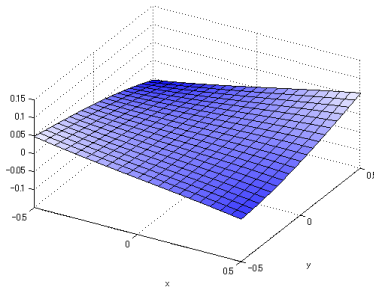

No. $1,2,3$

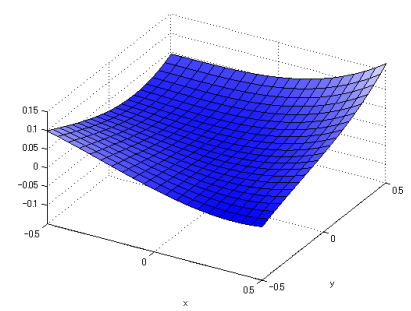

No. 4

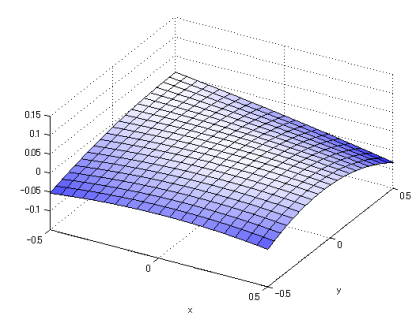

No. 5

Fig. 7 Test specimen shapes for the vibration measurement.

初めに作製した試験片 1 に対する実験結果，本手法(Ritz 法)および FEM(ANSYS)による解析結果を比較する. 第 1 次から第 4 次までの振動数比較を図 8, その振動モードを図 9 にそれぞれ示寸. 図 8 では赤(実線)が実験, 青 (一点鎖線)が本手法，緑(破線)が FEM による結果である，振動試験では，試験片の中央をウレタンスポンジで支 持することにより, 全周自由の境界条件を模擬し, インパルスハンマにより加振し, 軽量小型の加速度計により

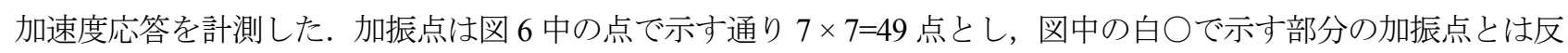
対面に加速度計を取り付けた．計測にはそれぞれの加振点について五回の打撃試験を実施して平均化を行ってい る.

実験により計測した振動数は第 1 次, 第 4 次では数值計算より $10 \%$ 程度低く, 第 2 次, 第 3 次では $10 \%$ 程度高 くなっているが，概ね一致した傾向を示している．この差は，ハンドレイアップ成形による繊維配向角度の微妙 なずれ，および層間樹脂量のバラツキが主な原因であると推測できる.しかしながら，図９に示す 通り，振動モ ード形状に関しては実験, 本手法, FEM ともよく一致しているため, 妥当な試験片が作製できていることが確認 できる．続いて図 10 に作製した五つの試験片の基本振動数を示す．赤(実線)が実験による結果，青(一点鎖線) が本解析手法による結果，緑(破線)が FEMによる結果である。 それぞれの試験片で実験結果は解析結果よりも低 い振動数を与えているが，傾向は一致している．また，最適な積層構成および形状を持つ試験片 1 が最も高い基 本振動数を与えている，これにより，本報における最適化手法の有用性が確認できた. 


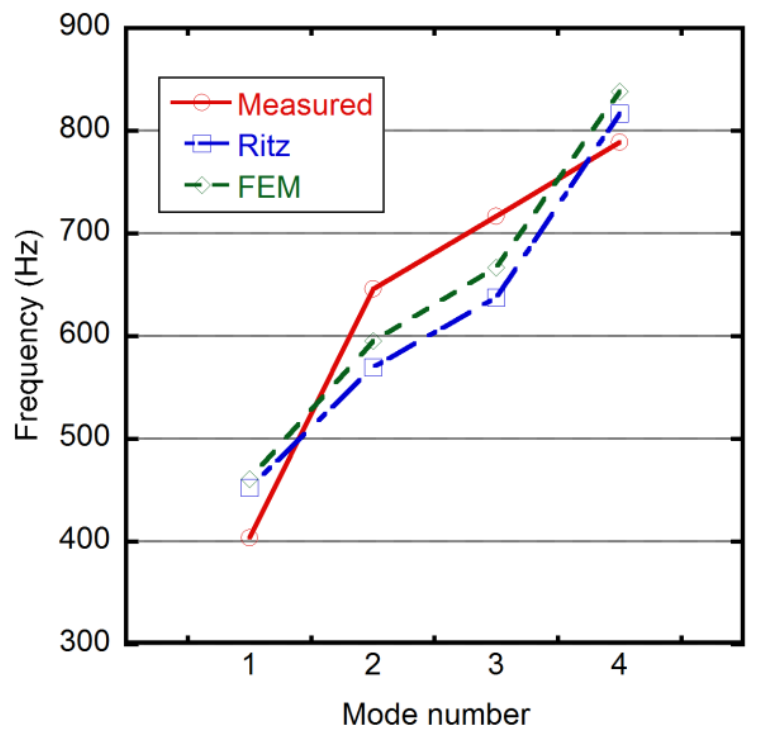

Fig. 8 The lowest four frequencies from the experiment, the Ritz method and the FEM
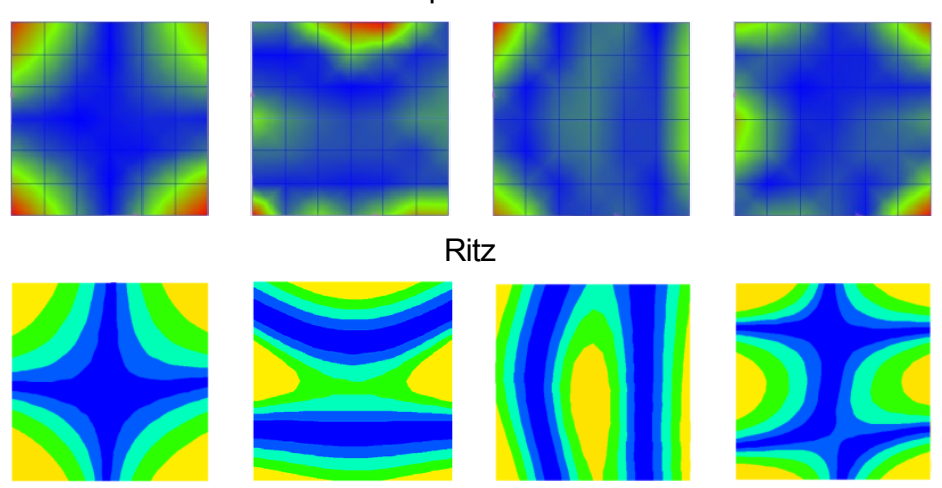

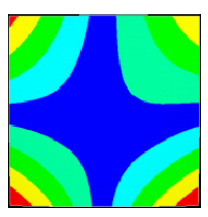

1 st

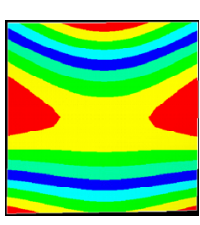

2nd

FEM

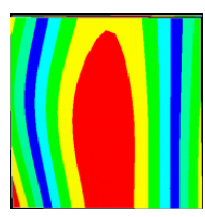

3rd

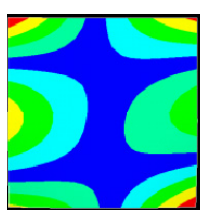

4th

Fig. 9 The lowest four vibration modes from the experiment, the Ritz method and the FEM.

\section{4. 結言}

複合材積層偏平シェルの基本振動数を最大化する目的で，形状および積層構成を同時に最適化した．最適化に は遺伝的アルゴリズムを用い, 振動解析にはRitz 法を用いた。 シェル形状は三次多項式により表現し, 各項の係 数を設計変数として採用することで，偏平シェル形状を任意に制御した．また，得られた結果をもとに試験片を 作製し，実験モード解析により振動数およびモード形状を測定した.

最適化計算で得られた複合材シェルは，一般的な形状および積層構成を持つシェルよりも高い振動数を示して いた. また，実験の結果と数值計算の結果もよく一致しており，最適化結果をもとに作製した試験片は他の試験 片よりも高い基本振動数を与えていた。 そのため, 本報で提案した, 複合材シェルに関する形状および積層構成 の統合最適化手法は，複合材シェルの振動数最大化問題に効果的であることが分かった. 


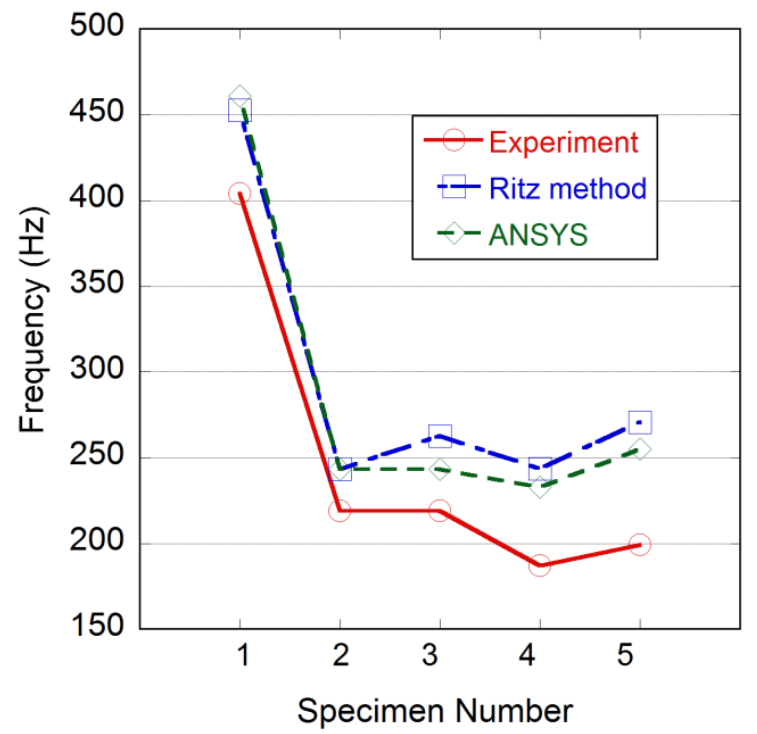

Fig. 10 Comparison between the optimum shell with other shells.

\section{謝 辞}

本研究は科学研究費補助金，基盤研究(B)(21360105)の助成を受けて実施されたものであり，ここに深甚なる感 謝の意を表す.

\section{文献}

(1) Qatu, M. S., "Review of shallow vibration research", Shock and Vibration Design, Vol. 25 (1992), pp. 3-5

(2) Liew, K. M. and Lim, C. M. and Kitipomchai, S., "Various theories for vibration on shallow shells: a review with bibliography”, Applied Mechanics Reviews, Vol. 50, (1997), pp. 431-444.

(3) Lam, K. Y. and Chun, L., "Dynamic analysis of clamped laminated curved panels", Composite Structures, Vol. 30, (1995), pp. 389-398.

(4) Berçin, A. N., "Natural frequencies of cross-ply laminated singly curved panels", Mechanics Research Communications Vol. 23, (1996), pp. 165-170.

(5) Bardell, N. S., Dunsdon, J. N., and Langley, R. S., "Free and forced vibration analysis of thin, laminated, cylindrically curved panels", Composite Structures, Vol. 38 (1997), pp. 453-462.

(6) Selmane, A. and Lakis, A. A., "Dynamic analysis of anisotropic open cylindrical shells", Computers \& Structures, Vol. 62, (1997), pp. 1-12.

(7) Soldatos, K. P. and Messina., A., "The influence of boundary conditions and transverse shear on the vibration of angle-ply laminated plates, circular cylinders and cylindrical panels", Computational Methods Applied Mechanics \& Engineering, Vol. 190, (2001), pp. 2385-2409.

(8) Kabir., H. R. H., "Application of linear shallow shell theory of Reissner to frequency response of thin cylindrical panels with arbitrary lamination", Composite Structures, Vol. 56 (2002), pp. 35-52.

（9）日本機械学会編，“シェルの振動と座屈ハンドブック”，(2003)，技報堂出版

(10) Raouf, R. A., "Tailoring the dynamic characteristics of composite panels using fiber orientation", Composite Structures, Vol. 29, (1994), pp. 259-267.

(11) Narita, Y., Itoh, M., Zhao, X. : Optimal design by genetic algorithm for maximum fundamental frequency of laminated shallow shells, Advanced Composite Letters, Vol.5, (1996), pp.21-24

(12) Narita, Y., Robinson, P. : Maximizing the fundamental frequency of laminated cylindrical panels using layerwise optimization, International Journal of Mechanical Sciences, Vol.48, (2006), pp.1516-1524

(13) 成田大祐, 成田吉弘, “不均一な曲率を持つ積層偏平シェルの振動解析法”, 日本機械学会論文集 (C 編), 72 巻 724 号(2006), pp. 3743-3750.

(14) Gürdal. Z., Haftka. R., and Hajela. P. “Design and Optimization of Laminated Composite Materials” (1999), John Wiley \& Sons

(15) Narita, Y. "Layerwise optimization for the maximum fundamental frequency of laminated composite plates", Journal of Sound and Vibration, Vol. 263 (2003), pp. 1005-1016 